\title{
What Remains: Pseudotranslation as Salvage Duncan Large
}

\section{Don Quixote and Pseudotranslation}

The story of Don Quixote famously comes to a grinding halt quite early on, in Chapter 8 of the First Part, when the titular hero is in the middle of a fight with a Basque squire. The reader is left hanging because, we are told: 'the unfortunate thing is that the author of this history left the battle in suspense at this critical point, with the excuse that he could find no more records of Don Quixote's exploits than those related here'. ${ }^{1}$ Thankfully our narrator, aided by 'Heaven, chance, and good fortune' (p. 76), is able to pick up the story again in the next chapter because, he tells us, in the Alcaná at Toledo one day he bumps into a lad selling parchments in Arabic script and (equally fortuitously) chances upon a Morisco translator who can tell him that the work he has stumbled upon is titled History of Don Quixote de la Mancha, written by Cide Hamete Benengeli, Arabic historian (p. 77). In exchange for 'fifty pounds of raisins and three bushels of wheat', and in little more than six weeks, the obliging Spanish-speaking Moor proceeds to translate the rest of the narrative that we are presented with, the day is saved and our story can continue.

To the contemporary reader such a metafictional conceit feels as if it is has come straight out of Borges (author of 'Pierre Menard, Author of the Quixote') or García Márquez (whose One Hundred Years of Solitude purports to be translated from the gypsy Melquíades' encoded Sanskrit manuscript), but of course the lines of literary filiation are quite otherwise. ${ }^{2}$ The shadowy figure of Cide Hamete Benengeli is name-checked another forty times over the course of the rest of the novel, as the conceit is sustained, and not surprisingly he has attracted a great deal of interest within more recent (postcolonially inspired) Cervantes scholarship. ${ }^{3}$ As with Black Athena, Martin Bernal's account of 'The Afroasiatic Roots of Classical Civilization' ${ }^{4}$ Cervantes places otherness at the origin of a Western tradition, and invites us to imagine that the tradition of modern Western prose fiction begins with the Arabic tale-telling of a Manchegan Moor. The intercultural detour via Cide Hamete Benengeli orientalises Cervantes' narrative, it distances and displaces it, playfully devolving narrative agency and divesting Cervantes himself of the responsibility for the veracity of his text: 'if any objection can be made against the truth of this history,' we read, 'it can only be that its narrator was an Arab - men of that nation being ready liars' (p. 78).

Now of course while Cide Hamete may be a shadowy figure, the nameless Spanish-speaking Moor who supposedly translates the great majority of the narrative for us is even more so. ${ }^{5}$ Nevertheless, the fact remains that the great majority of Don Quixote purports to be a translation, ${ }^{6}$ and it is on that that I want to focus in the remarks that follow. For there has been at least an equal amount of interest in Cervantes' narrative conceit from within translation studies in recent years, making the novel in André Lefevere's words 'perhaps the most famous pseudotranslation in world literature'. ${ }^{7}$ The term 'pseudotranslation' was in use by the mid-twentieth century, ${ }^{8}$ but it was not until the 1980s that it acquired its modern sense and began to be applied by Julio-César Santoyo and Gideon Toury to what Anton Popovič had termed 'fictitious translations'. 9 Pseudotranslations are defined by Anthony Pym as 'texts presented as translations but which have no corresponding source text' ${ }^{10}$ more succinctly, Emily Apter has called pseudotranslation a case of 'Translation with No Original'. ${ }^{11}$ In the wake of Toury's pioneering work there has been a great deal of further theoretical work in this area over the last thirty years, with the tempo quickening markedly since the turn of the millennium. ${ }^{12}$ For Pym, the liminal status of pseudotranslations calls into question translators' originality and creativity more generally. Other scholars (following 
Toury and his systems-oriented approach) have focused on what the self-presentation as translation allows a text to achieve which it would not have been able to otherwise: the avoidance of censorship, perhaps, and pursuit of social criticism in a text such as Montesquieu's Lettres persanes (1721), ${ }^{13}$ or the ability to smuggle adventurous new literary forms into a target culture as in Holz and Schlaf's Papa Hamlet (1889), which radicalised German Naturalism through a purported translation from the Norwegian. ${ }^{14}$

In the case of Don Quixote, on one level its pseudotranslational quality is just a good joke: Cervantes employs the trope of pseudotranslation as part of his retrospective project to satirise the chivalric romances, whose authors routinely claimed to have translated their tales from obscure foreign-language sources. ${ }^{15}$ The question of pseudotranslation intersects particularly fruitfully with the theme of 'salvage', though, too: salvage, after all, is the flipside of loss (and translators certainly know a thing or two about that). As far as Don Quixote is concerned, we are told nothing about what happens to the 'original' Arabic-script manuscript after it has been translated: it may still exist, but in any event it is not available to the reader. Pseudotranslation thus covers for the original and substitutes for it (surreptitiously occluding the fact that no original actually exists). In Don Quixote the original manuscript is simply unavailable; in similar cases which I will come on to, the original is said to have been lost: pseudotranslation is thus presented as an act of salvage in a quite concrete sense. Even in the case of Don Quixote, the circumstances are such that the (great majority of the) text gets salvaged by chance from oblivion. The narrator is at pains to emphasise just what a chance occurrence it was that he should happen upon the manuscript and a translator who could decipher it for him. Had it not been for this conjunction of circumstances, we are led to surmise, the greater part of the Don's adventures would not have come down to us. Carroll B. Johnson traces the sequence of chance occurrences back even further, and points out that the narrative is salvaged from the silkworms:

At the metafictional level, the text we read owes its existence to the Toledo silk industry and its requirements for paper. What might have become of Cide Hamete Benengeli's manuscript had it not been bundled up to sell to a silk manufacturer as food for worms, and been discovered there by the second author in part I, chapter 9 ? $^{16}$

In this sense, pseudotranslations can be viewed as a subset of the wider category of fictions that are metafictionally framed as having been salvaged and come down to us by some lucky chance. These techniques were developed and exploited from early on in the rise of the novel and include things like the chance discovery of correspondence, or found manuscripts (e.g. Potocki's The Manuscript Found in Saragossa), including the countless examples of the posthumous discovery of papers which required a (fictional) editor to bring to publication (e.g. Goethe's Werther). Such techniques can, of course, reach veritably baroque levels of convolution, as in E.T.A. Hoffmann's Tomcat Murr (1819-21), where the cat's autobiography is 'accidentally' interleaved with 'waste papers' consisting of pages supposedly torn from the narrative of Kapellmeister Johannes Kreisler. These are so many cross-cultural tropes familiar to us from literary history, but I want to argue that there is a specificity about pseudotranslations in this context. After a few more examples of this kind of playful pseudotranslation I will consider the more serious side to the question, when pseudotranslation shades into outright forgery and fraud.

\section{Shakespeare}

What is remarkable about the example of Don Quixote is how modern (indeed postmodern) and meta it all feels: as with Hoffmann's Tomcat Murr or Sterne's Tristram Shandy before it 
(both of which took their inspiration from Cervantes in many respects), the novel can easily wrong-foot modern readers who are perhaps not expecting to encounter such 'postmodern' knowingness at the 'premodern' beginning of the novelistic tradition. Moving on from Don Quixote at this point, I will move sideways to his contemporary Shakespeare, and consider two equally playful contemporary postmodern examples involving Shakespearean texts as pseudotranslations. Now we know Shakespeare's debt to translations such as North's Plutarch and Florio's Montaigne, but it takes the postmodern period to introduce the idea of Shakespeare himself as pseudotranslated. A film which takes its inspiration from Shakespeare in numerous ways (not least its title) is Star Trek VI: The Undiscovered Country (1991). Here the crew of the Enterprise invite the crew of a Klingon battlecruiser to dinner: Klingon Chancellor Gorkon proposes a toast to 'the undiscovered country' (figured as a peaceful future) and Spock cites the Shakespearean source, but Gorkon retorts: 'You have not experienced Shakespeare until you have read him in the original Klingon.' ${ }^{17}$ This remark has in turn inspired the Klingon Language Institute to 'restore' Hamlet in its entirety to its 'original' Klingon, and excerpts from the play have been duly performed. ${ }^{18}$ In the introduction to the printed edition the 'spontaneous, direct and vibrant verse' of the Klingon version is contrasted with the 'flaccid, ponderous, convoluted meanderings' of the English version, making it obvious that the latter is a derivative work. ${ }^{19}$

This is all very tongue-in-cheek, as is my second modern Shakespearean example, from Tom Stoppard. The third and final play in Stoppard's trilogy Coast of Utopia (2002) is actually titled Salvage, but for my purposes here I am actually more interested in his masterpiece Arcadia (1993). Early in that play, in the part set in 1809, thirteen-year-old Thomasina Coverley is struggling to translate a piece of Latin poetry for her tutor Septimus Hodge:

THOMAsina: Solio insessa . . . in igne . . . seated on a throne ... in the fire . . . and also on a ship . . . sedebat regina ... sat the queen ... [...] the wind smelling sweetly ... purpureis velis ... by, with or from purple sails - [...] was like as to - something by, with or from lovers - oh, Septimus! ${ }^{20}$

After some more of this agonising, Septimus duly steps in and takes over:

[SEPTIMUS:] Now, where are we? Let me see if I can attempt a free translation for you. At Harrow I was better at this than Lord Byron.

(He takes the piece of paper from her and scrutinizes it, testing one or two Latin phrases speculatively before committing himself.)

Yes - 'The barge she sat in, like a burnished throne ... burned on the water ... the something - the poop was beaten gold, purple the sails, and - what's this? oh yes, - so perfumed that -

THOMASINA: (Catching on and furious) Cheat! $!^{21}$

Thomasina realises that she has been had: that the 'Latin poetry' she has been sweating over is actually already a neo-Latin translation by Septimus of Enobarbus' description of Cleopatra in Act II, Scene 2 of Shakespeare's Antony and Cleopatra. Between gobbets of translation, Thomasina has been fretting over the lost plays of the classical tragedians, but Septimus urges her to celebrate and savour all that remains. Arcadia is about acts of salvage in many ways, not least literary, and what turns out to be Thomasina's broken backtranslation from Shakespeare's 'little Latin' serves as a salutary reminder that even as it salvages, (pseudo)translation brings with it loss. As Paul Edwards remarks, 'Thomasina's stumbling version proves that translation is a one-way process, and that what is once lost 
remains lost' ${ }^{22}$ In the universe of Stoppard's play (and not only there), translation remains subject to the Second Law of Thermodynamics.

\section{Walpole and Macpherson}

These examples of pseudotranslation in a Shakespearean context only work because we are on sure ground, we know our Shakespeare and know that there is a Shakespearean original against which these upstart texts can be set and measured. What if we cannot be so sure about the original, though? Let us take two examples of pseudotranslation from the eighteenth century which have by now become rather infamous.

Horace Walpole's The Castle of Otranto (1764), the original Gothic novel, was first published as having been 'Translated by William Marshal, Gent. From the Original Italian of Onuphrio Muralto, Canon of the Church of St. Nicholas at Otranto.' Unfortunately, Walpole got carried away in his introduction and supplied a hostage to fortune, promising of his work: 'Should it meet with the success I hope for, I may be encouraged to re-print the original Italian'. ${ }^{23}$ He was subsequently hoist with his own petard, since the book did become wildly popular, and he soon had to confess (in the preface to the second edition of 1765) that there was no Italian original, that he had made it all up. ${ }^{24}$

Another wildly successful pseudotranslation from the 1760s was James MacPherson's Ossian (described by Douglas Robinson as 'the textbook case of pseudotranslation'). ${ }^{25}$ No sooner had Macpherson published his Fragments of Ancient Poetry Collected in the Highlands of Scotland, and Translated from the Gaelic or Erse Language (1760) than he was challenged as to their provenance. Unlike Walpole, though, he toughed it out, despite never producing the originals that he claimed existed. Indeed it took another century after his death before, as Robinson puts it, 'by the end of the nineteenth century it was finally established that the Gaelic originals from which Macpherson supposedly worked, and which had been published after his death, were actually Macpherson's own translations into bad Gaelic of his original English poems'. ${ }^{26}$

\section{The Book of Mormon and Nietzsche}

Macpherson's Ossian is usually categorised nowadays as a literary forgery, but its deception was harmless enough, and indeed in many ways it acted as a positive force for good: it contributed to the burgeoning enthusiasm for the supposed long-lost national bard (putting Scotland on a par with other native cultures of Europe) and in turn spawned Romantic nationalistic spin-offs elsewhere across Europe. ${ }^{27}$ My two final examples of pseudotranslations are of more dubious effectiveness, more scandalous, for their authors engaged in elaborate deceptions, covering over their tracks by concocting stories to explain the absence of source texts.

Joseph Smith published The Book of Mormon in 1830, having purportedly translated it from the 'Reformed Egyptian' on a set of golden plates to which he had been directed by an angel. ${ }^{28}$ Mormon apologists have been quick to analyse the language of The Book of Mormon and declare it to be obviously 'translation English'; ${ }^{29}$ Mark Twain was less generously disposed and pulled no punches when he reviewed the book in Roughing It (1872), commenting: 'The book seems to be merely a prosy detail of imaginary history, with the Old Testament for a model; followed by a tedious plagiarism of the New Testament. ${ }^{30}$ In our time Gideon Toury analysed The Book of Mormon as a case study in pseudotranslation on the basis of its stylistic features, arguing (of its verbatim borrowings from the King James Bible): 'in terms of its linguistic formulation, the Book of Mormon is an extreme case of what I have 
called 'overdoing it vis-à-vis the source it is modelled on', which is so typical of fictitious translations'. ${ }^{31}$ Douglas Robinson, similarly, strains to preserve his neutrality as he summarises Smith's cover story:

In the case of The Book of Mormon, not only did the source text not exist in any public or historical form prior to the translation process (it supposedly lay buried in a hill for 2000 years); after the translation was completed it was taken back up to heaven by the angelic messenger who directed its translator to its location and the work of translation, so that all that remains of it today is a series of 'testimonials' from upright citizens that they saw with their own eyes the golden plates on which the source text was etched. ${ }^{32}$

There is no longer any doubt about the fraudulence of my last example, either, a philosophical one: the text first published in 1951 as Friedrich 'Nietzsche's suppressed final work', My Sister and I. In this case the claim was that Nietzsche had not spent his final decade incurably insane but had been able to pen a final manuscript in secret which had been smuggled out of his Jena asylum and ultimately translated into English before - oops! - the original manuscript was destroyed in an American warehouse. My Sister and I proved a scandal on publication, not only because of the supposed circumstances of its composition and its disavowal by the daughter of the supposed editor and translator Oscar Levy, but especially because of its salacious subject matter (the book features an incestuous relationship between Nietzsche and his sister, and an affair with Richard Wagner's wife Cosima). On its publication My Sister and I was denounced as a forgery by the leading Nietzsche scholar Walter Kaufmann, and Kaufmann later received a signed affidavit from its actual author, David George Plotkin. ${ }^{33}$

\section{Conclusion}

In conclusion I would like to step back from these examples and consider some of the ways in which pseudotranslations can teach us about translations more generally. After all, perhaps pseudotranslations are not so anomalous, not such a special case? Sometimes, for example, originals do actually get lost, and there are genuine cases where texts exist only because of acts of translation. ${ }^{34}$ Ironically, sections of the original French-language manuscripts of Potocki's The Manuscript Found in Saragossa were later lost and had to be back-translated into French from a Polish translation. ${ }^{35}$ Even the New Testament of the Christian Bible has its doubters who take the view (known as the Aramaic primacy) that the koine Greek text that has come down to us is in fact only a translation from Aramaic sources, and that some of its awkwardnesses can be resolved by 'back-translating'. ${ }^{36}$

More interestingly, I think, the cases of pseudotranslation that I have been reviewing, which invoke lost and unavailable original source texts, invite us to reconsider the standard default relation between a translation and its original. Most translations are not orphans shorn of their 'parent' text, but they have at least reached the age of reason and left home. Unless we are reading a bilingual edition we never have the original to hand when we are reading a translation and are always having to assume that the original (still) exists somewhere else. Stoppard's Thomasina Coverley has reminded us that all texts get eroded in the process of translation (so that a back-translation will never reconstitute the pristine original): in the normal course of events translations, of course, usurp the place of their parent text in the receiving culture and to all intents and purposes become a new original text - as was the case, for example, with the King James Version of the English Bible, or indeed Jerome's Latin Vulgate before it (and the Greek Septuagint before that). Yet in the normal course of events 
the original still remains once the translation has been produced: our perspective on it may have been altered by the existence of a new translation, but the text itself has not been degraded by the act of translation. At least in principle the possibility exists of returning to the same well and drawing again from the same source - and in the case of a text like Don Quixote that is indeed what happens, all the time, with fresh retranslations.

When the original fails to be produced, the reader of a self-declared translation simply has to take it on trust that the original exists, just as we are asked to accept the veracity of an autobiography. Readers, of course, do not normally concern themselves with questions about the status of the original (and translations do their best to occlude them) but there is nonetheless an assumption of trust between the reader and the translator, an unspoken pact which I will call (by analogy with Lejeune) the 'translational pact'. ${ }^{37}$ What pseudotranslations do is reveal that this implicit pact can be broken (qualifying and problematising it). As Emily Apter puts it: 'cases of pseudotranslation reveal the fundamental unreliability of a translation's claim to approximating the original in another tongue. [...] all translations qualify as a form of linguistic forgery'. ${ }^{38}$ I would like to turn this claim around, though, and put it more positively, following Walter Benjamin. In his essay on 'The Task of the Translator', Benjamin famously argues that translations grant their original texts an afterlife. ${ }^{39}$ It is not necessary, then, for a text to be a pseudotranslation to perform an act of salvage, purportedly rescuing a text from the wreck of a lost (or otherwise unavailable) original. Even when an original exists, translation performs a kind of salvage operation and acts as a kind of lifeboat which rescues a text from the passing of time and keeps it afloat for posterity. Translations always 'come after' their originals: they salvage the message from a medium which is (or threatens to become) outdated; they freshen it up and give it new life. Ultimately, the fate from which all translations rescue texts is obscurity, the potential oblivion of neglectful indifference.

\footnotetext{
${ }^{1}$ Miguel de Cervantes Saavedra, The Adventures of Don Quixote, trans. J. M. Cohen (Harmondsworth: Penguin, 1950), p. 74. Further parenthetic page references in the main text are to this edition.

${ }^{2}$ On Borges and Cervantes, see: Juan Goytisolo, 'Borges, Cervantes et la tradition orientale', Horizons maghrébins 41 (1999), 9-12; Ilan Stavans and William P. Childers, 'What Borges Learned from Cervantes: On Language, and the Thin Line Between Fiction and Reality', Literary Hub, 20 April 2016 (http://lithub.com/what-borges-learned-from-cervantes/). On García Márquez and Cervantes, see Aníbal González, 'Translation and Genealogy: One Hundred Years of Solitude', in Bernard McGuirk and Richard Cardwell (eds.), Gabriel García Márquez: New Readings (Cambridge: Cambridge University Press, 1987), pp. 65-79.

${ }^{3}$ See e.g. Howard Mancing, 'Cide Hamete Benengeli vs. Miguel de Cervantes: The Metafictional Dialectic of Don Quijote', Cervantes 1/1-2 (1981), 63-81; R. M. Flores, 'The Rôle of Cide Hamete in Don Quixote', Bulletin of Hispanic Studies 59/1 (1982), 3-14; Elizabeth Welt Trahan, 'The Arabic Translator in Don Quixote: His Master's Voice and Victim', in Marilyn Gaddis Rose (ed.), Translation Perspectives: Selected Papers, 1982-1983 (Binghamton, NY: Translation Research and Instruction Program, 1984), pp. 71-85; Devin J. Stewart, 'Cide Hamete Benengeli, Narrator of Don Quijote', Medieval Encounters 3/2 (1997), 111-27; William Childers, 'Cide Hamete Benengeli: The Other Within', in Transnational Cervantes (Toronto, Buffalo and London: University of Toronto Press, 2006), pp. 68-76; E. C. Graf, 'Don Quijote and Islam: When an Arab Laughs in Toledo', in Cervantes and Modernity: Four Essays on 'Don Quijote' (Lewisburg, PA: Bucknell University Press, 2007), pp. 21-55.
} 
${ }^{4}$ See Martin Bernal, Black Athena: The Afroasiatic Roots of Classical Civilization, 3 vols. (New Brunswick, NJ: Rutgers University Press; London: Free Association Books, 19872006).

${ }^{5}$ It is of course no coincidence that he should be encountered in Toledo, seat of the historic Toledo School of Translators in the medieval period. Gerard Wiegers offers convincing evidence that Cervantes' model was Miguel de Luna: see 'The Granada Lead Books Translator Miguel de Luna as a Model for Both the Toledan Morisco Translator and the Arab Historian Cidi Hamete Benengeli in Cervantes' Don Quixote', in Kevin Ingram and Juan Ignacio Pulido Serrano (eds.), The Conversos and Moriscos in Late Medieval Spain and Beyond, vol. 3 (Leiden: Brill, 2016), pp. 150-63.

${ }^{6}$ Whether from Arabic or from Aljamía (a dialect of Spanish spoken by the Morisco community and written in Arabic script), is disputed. See Carroll B. Johnson, 'Phantom PreTexts and Fictional Authors: Sidi Hamid Benengeli, Don Quijote and the Metafictional Conventions of Chivalric Romances', Cervantes 27/1 (2007), 179-99 (pp. 190-92). ${ }^{7}$ André Lefevere, 'Pseudotranslations', in Olive Classe (ed.), Encyclopedia of Literary Translation into English, 2 vols. (London and Chicago: Fitzroy Dearborn, 2000), vol. 2, pp. 1122-23 (p. 1122).

${ }^{8}$ Cf. José Ortega y Gasset, 'The Misery and the Splendor of Translation', trans. Elizabeth Gamble Miller, in Lawrence Venuti (ed.), The Translation Studies Reader (London and New York: Routledge, 2000 [1937]), pp. 49-63 (p. 60), and Theodore Savory, The Art of Translation (London: Jonathan Cape, 1968 [1957]), pp. 151-56.

${ }^{9}$ See Anton Popovič, Dictionary for the Analysis of Literary Translation (Edmonton: University of Alberta, 1976), p. 20; Julio-César Santoyo, 'La traducción como técnica narrativa', in Actas del IV. Congreso de la Asociación Española de Estudios AngloNorteamericanos (Salamanca: University of Salamanca, 1984), pp. 37-53 (pp. 46-49); Gideon Toury, 'Translation, Literary Translation and Pseudotranslation', Comparative Criticism 6 (1984), 73-85. See also Toury, Descriptive Translation Studies and Beyond (Amsterdam and Philadelphia: John Benjamins, 1995), pp. 40-52 ('Excursus A: Pseudotranslations and their Significance').

${ }^{10}$ Anthony Pym, 'The Translator as Non-Author, and I am Sorry about That', in Claudia Buffagni, Beatrice Garzelli and Serenella Zanotti (eds.), The Translator as Author: Perspectives on Literary Translation (Berlin: LIT, 2011), pp. 31-43 (p. 36).

${ }^{11}$ Emily Apter, 'Translation with No Original: Scandals of Textual Reproduction', in Sandra Bermann and Michael Wood (eds.), Nation, Language, and the Ethics of Translation (Princeton, NJ and Oxford: Princeton University Press, 2005), pp. 159-74; reproduced in Apter, The Translation Zone: A New Comparative Literature (Princeton, NJ: Princeton University Press, 2006), pp. 210-25.

${ }^{12}$ For the best overview of recent work, see Brigitte Rath, 'Pseudotranslation', ACLA State of the Discipline Report, 2014-15 (available online at http://stateofthediscipline.acla.org/entry/pseudotranslation).

${ }^{13}$ See Julio-César Santoyo, 'Blank Spaces in the History of Translation', in Georges L. Bastin and Paul F. Bandia (eds.), Charting the Future of Translation History (Ottawa: University of Ottawa Press, 2006), pp. 11-43 (pp. 19-22: 'Pseudo-translations'); Julio-César Santoyo, 'Traducción, seudotraducción y reescrituras: El paradigma de las Lettres persanes de Montesquieu', in Historia de la traducción: Viejos y nuevos apuntes (León: University of León, 2008), pp. 237-50; Sigrid Kupsch-Losereit, 'Pseudotranslations in 18th-Century France', in Klaus Kaindl and Karlheinz Spitzl (eds.), Transfiction: Research into the Realities of Translation Fiction (Amsterdam: John Benjamins, 2014), pp. 189-201. 
${ }^{14}$ See Toury, 'The Enlightening Case of Papa Hamlet', in Descriptive Translation Studies and Beyond, pp. 47-52.

15 Cf. Howard Mancing, 'Cervantes and the Tradition of Chivalric Parody', Forum for Modern Language Studies 11/2 (April 1975), 177-91, and Johnson, 'Phantom Pre-Texts and Fictional Authors'.

${ }^{16}$ Carroll B. Johnson, Cervantes and the Material World (Urbana and Chicago: University of Illinois Press, 2000), p. 6.

${ }^{17}$ Star Trek VI: The Undiscovered Country, dir. Nicholas Meyer (Paramount Pictures, 1991).

${ }^{18}$ Two scenes were performed for the film's DVD extras by Commedia Beauregard, St. Paul, Minnesota, 2008.

${ }^{19}$ The Klingon Hamlet: The Restored Klingon Version, trans. Nick Nicholas and Andrew Strader, ed. Mark Shoulson (New York: Pocket Books, 2000), p. xiii.

${ }^{20}$ Tom Stoppard, Arcadia (London and Boston: Faber and Faber, 1993), Act I, Scene 3 (p. $35)$.

${ }^{21}$ Ibid., p. 39.

${ }^{22}$ Paul Edwards, 'Science in Hapgood and Arcadia', in Katherine E. Kelly (ed.), The

Cambridge Companion to Tom Stoppard (Cambridge: Cambridge University Press, 2001), pp. 171-84 (p. 179). Cf. also Hersh Zeifman, 'Stoppard and Shakespeare', in Martin Procházka et al. (eds.), Renaissance Shakespeare: Shakespeare Renaissances. Proceedings of the Ninth World Shakespeare Congress (Newark: University of Delaware Press, 2014), pp. 393-400 (pp. 397-8).

${ }^{23}$ Horace Walpole, 'Translator's Preface', in The Castle of Otranto, A Story (London: Lownds, 1764), pp. iii-ix (p. vii).

${ }^{24}$ Not that the pretence has been entirely dispelled: Amazon still lists Onuphrio Muralto as the author of a dozen older editions of the book.

${ }^{25}$ Douglas Robinson, 'Pseudotranslation', in Mona Baker (ed.), Routledge Encyclopedia of Translation Studies (London and New York: Routledge, 1998), pp. 183-5 (p. 183).

${ }^{26}$ Ibid., p. 184.

${ }^{27}$ See Howard Gaskill (ed.), The Reception of Ossian in Europe (London: Thoemmes Continuum, 2004).

${ }^{28}$ Circumstances which were not dissimilar, in other words, to those claimed for the production of the fraudulent 'Granada Lead Books' in Cervantes' time. See Mercedes García-Arenal and Fernando Rodríguez Mediano, The Orient in Spain: Converted Muslims, the Forged Lead Books of Granada, and the Rise of Orientalism, trans. Consuelo LópezMorilla (Leiden and Boston: Brill, 2013).

${ }^{29}$ Sidney B, Sperry, 'The Book of Mormon as Translation English', Journal of Book of Mormon Studies 4/1 (1995 [1935]), 209-17. Even Mormon apologists freely admit, though, that in 'translating' the text Smith was literally talking through his hat, with the aid of a 'seer stone' (see e.g. http://www.mrm.org/translation).

${ }^{30}$ Mark Twain, Roughing It (Hartford, CN: American, 1872), p. 127.

${ }^{31}$ Toury, 'Enhancing Cultural Changes by Means of Fictitious Translations', in Eva Hung (ed.), Translation and Cultural Change: Studies in History, Norms and Image-Projection (Amsterdam and Philadelphia: John Benjamins, 2005), pp. 3-17 (p. 13). See also David J. Shepherd, 'Rendering Fiction: Translation, Pseudotranslation, and The Book of Mormon', in Francis J. Beckwith, Carl Mosser and Paul Owen (eds.), The New Mormon Challenge: Responding to the Latest Defenses of a Fast-Growing Movement (Grand Rapids, MI: Zondervan, 2002), pp. 367-95.

${ }^{32}$ Douglas Robinson, Who Translates? Translator Subjectivities Beyond Reason (Albany: SUNY Press, 2001), pp. 54-61 (pp. 54-55). 
${ }^{33}$ See Walter Kaufmann, Nietzsche: Philosopher, Psychologist, Antichrist, 3rd edn. (Princeton, NJ: Princeton University Press, 1968), p. 496. More recently the book's authenticity has also been roundly rejected by Oscar Levy scholar Leila Kais, in 'Le Nietzschéanisme, c'est moi': Oscar Levy und die Einführung Nietzsches in England (Berlin: Parerga, 2010), pp. 304-11. Not that this has deterred Walter Stewart from defending the book's authenticity in our time: see Walter Stewart, Nietzsche, 'My Sister and I': A Critical Study (Bloomington, IN: Xlibris, 2007), and Friedrich Nietzsche, 'My Sister and I': Investigation, Analysis, Interpretation (Bloomington, IN: Xlibris, 2011).

${ }^{34}$ See Santoyo, 'Blank Spaces in the History of Translation', pp. 28-30 ('Translated Texts as Survivors of Lost Originals').

${ }^{35}$ See Ian Maclean, 'Introduction', in Jan Potocki, The Manuscript Found in Saragossa, trans. Maclean (London: Penguin, 1996), pp. xi-xviii (p. xiii).

${ }^{36}$ See The Holy Bible: From Ancient Eastern Manuscripts, trans. George M. Lamsa (Philadelphia: Holman, 1957).

${ }^{37}$ Cf. Philippe Lejeune, Le pacte autobiographique (Paris: Seuil, 1975).

${ }^{38}$ Apter, The Translation Zone, p. 220.

${ }^{39}$ Walter Benjamin, 'The Task of the Translator', trans. Harry Zohn, in Venuti (ed.), The Translation Studies Reader, pp. 15-25 (pp. 16-17). 